University of Nebraska - Lincoln

DigitalCommons@University of Nebraska - Lincoln

U.S. Environmental Protection Agency Papers

U.S. Environmental Protection Agency

2001

\title{
On the Effectiveness of State Anti-Corporate Farming Laws in the United States
}

Rick Welsh

Clarkson University, Center for Environmental Management, Potsdam, NY 13617, USA

Chantal Line Carpentier

North American Commission for Environmental Cooperation, 393 Rue St-Jacques O., Bureau 200,

Montreal, Quebec H2Y 1N9, Canada

Bryan Hubbell

Innovative Strategies \& Economics Group, EPA-OAQPS, MD-15, RTP, NC 27711, USA

Follow this and additional works at: https://digitalcommons.unl.edu/usepapapers

Part of the Civil and Environmental Engineering Commons

Welsh, Rick; Carpentier, Chantal Line; and Hubbell, Bryan, "On the Effectiveness of State Anti-Corporate Farming Laws in the United States" (2001). U.S. Environmental Protection Agency Papers. 2.

https://digitalcommons.unl.edu/usepapapers/2

This Article is brought to you for free and open access by the U.S. Environmental Protection Agency at DigitalCommons@University of Nebraska - Lincoln. It has been accepted for inclusion in U.S. Environmental Protection Agency Papers by an authorized administrator of DigitalCommons@University of Nebraska - Lincoln. 


\title{
On the Effectiveness of state anti-corporate farming laws in the United States
}

\author{
Rick Welsh ${ }^{\mathrm{a}, *}$, Chantal Line Carpentier ${ }^{\mathrm{b}}$, Bryan Hubbell ${ }^{\mathrm{c}}$ \\ a School of Liberal Arts, Clarkson University, Center for Environmental Management, Potsdam, \\ NY 13617, USA \\ ${ }^{\mathrm{b}}$ North American Commission for Environmental Cooperation, 393 Rue St-Jacques O., Bureau 200, \\ Montreal, Quebec H2Y 1N9, Canada \\ ' Innovative Strategies \& Economics Group, EPA-OAQPS, MD-15, RTP, NC 27711, USA
}

Received 17 May 2000; received in revised form 12 February 2001; accepted 12 July 2001

\begin{abstract}
Structural changes in US agriculture toward a more corporate-oriented and vertically aligned system have focused attention on the relative efficacy of the anti-corporate farming laws of nine Midwestern states. Using state-level data from a survey of agricultural lawyers and the U.S. Census of Agriculture, we find that the restrictiveness of the laws vary among states, and the relative restrictiveness of the laws have changed over time. Also, strengthening a law tends to limit acreage under non-family corporate ownership arrangements. (C) 2001 Elsevier Science Ltd. All rights reserved.
\end{abstract}

Keywords: Corporate farms; State agriculture policy; Vertical coordination and integration

\section{Introduction}

Recent changes in US agriculture toward a vertically integrated structure have prompted debates over the appropriate role of corporations in agriculture. These debates have focused attention on the anti-corporate farming laws of nine contiguous

\footnotetext{
* Corresponding author. Tel.: +1-315-268-3988.

E-mail addresses: welshjr@clarkson.edu (R. Welsh); carpentier@ccemtl.org (C. L. Carpentier); hubbell.bryan@epa.gov (B. Hubbell).

The findings and opinions expressed in this article are the authors' and not necessarily of the U.S. Environmental Protection Agency.
} 
Midwestern states: Iowa, Kansas, Minnesota, Missouri, Nebraska, North Dakota, Oklahoma, South Dakota, and Wisconsin. The state laws of interest are labeled "anticorporate" because, for the most part, they "provide that corporations or other investment type entities shall not engage in farming, nor shall they directly or indirectly own or otherwise acquire interests in agricultural land" (Pedersen and Meyer, 1995: 45). Taken together the states form a kind of anti-corporate farming zone in the central section of the US.

The laws were put in place starting in the early seventies. The laws were designed to promote family-owned farming operations through limiting the role of corporations in agricultural production. For example, Minnesota's anti-corporate farming law specifically states that it is in the interests of the state to promote and protect:

"the family farm as a basic economic unit, to insure it as the most socially desirable mode of agricultural production, and to enhance and promote the stability and well-being of rural society in Minnesota and the nuclear family."

The laws were also enacted in response to fears that agribusiness conglomerates might gain control of production and marketing of a substantial portion of the food supply, and so be able to control prices and boost profits (Welsh, 1998).

The design of the laws vary between states. However, in general the laws create a hierarchy of regulation of ownership arrangements in agriculture. Non-family corporations are the most likely to have their activities restricted under anti-corporate farming laws. Family corporations, partnership arrangements and sole proprietorships have fewer or no restrictions placed on them. One of the more common restrictions placed on non-family corporate farms or other regulated entities is a cap on acres of land owned (Welsh, 1998).

With the exception of Nebraska, whose constitutional amendment came into effect in 1982, the states had their laws in place by 1975 . However, the laws have changed over time. Missouri's law was relaxed in 1993 to allow Premium Standard Farms to establish operations in part of the state, Oklahoma "clarified" its law in 1991 to attract more corporate investment in agriculture, and in 1995, Kansas began to allow counties to exempt themselves from its law (Hamilton, 1995). In 1988 and 1998 South Dakota placed more restrictions on corporate farms.

Despite efforts to establish, strengthen or relax such laws, we found no systematic evaluation of the overall efficacy of the laws, nor if differences between states' laws, and changes in the laws, have had measurable impacts. In this paper we investigated the potential impact of the laws. Specifically, we attempted to discern what impact, if any, restrictions on non-family corporations have had, at the state level, on: (1) the percentage of acres owned by non-family corporations; and (2) the overall percentage of non-family corporate farms.

\section{Data and methods}

Data was gathered from the US Census of Agriculture for 1987 and 1997 on percentage of land owned by non-family corporate farms and overall percentages of 
non-family corporate farms for anti-corporate farming states (AC states) and a number of other central states (OC states): Montana, Wyoming, Colorado, New Mexico, Texas, Arkansas, Kentucky, Tennessee, Illinois, Indiana, Ohio, and Michigan. The criteria used for choosing OC states was whether a state bordered a state with an anti-corporate law, or was considered part of the Corn Belt region. In this way we attempted to control for the type of agriculture practiced, in order to isolate the possible impacts of the laws. ${ }^{1}$ In 1997 in AC states, the average percentage of farms that were non-family corporations was $0.28 \%$, with acreage averaging about $1.82 \%$. In OC states the figures were $0.41 \%$ and $0.94 \%$, respectively.

To construct an index of the laws' restrictiveness over time we surveyed agricultural lawyers deemed by their peers as experts on anti-corporate farming laws. To obtain the names of the agricultural lawyers, we initially identified knowledgeable informants and queried them as to a list of experts. Each of these experts were subsequently contacted and asked for a list of experts. This iterative process continued until a "core" group of 19 experts were identified. This type of purposive sampling is a common qualitative research methodology. It is useful for identifying and gathering data from small groups of people with specialized knowledge, experiences, or insight (Patton, 1990). Nineteen surveys were mailed and 15 complete and usable surveys were returned. The surveyed lawyers worked in private practice, academia and non-governmental organizations interested in agricultural policy.

Respondents rated the laws from 1 to 5 for each year the laws were in effect from 1974 to 1997 . This time period was chosen to coincide with the establishment of the laws (laws were in place by 1975 except for Nebraska's in 1982). Lower ratings indicate less restrictiveness. The results are the weighted averages of the respondents' ratings for each state. The restrictiveness ratings are presented in Table 1.

Ordinary Least Squares (OLS) regression analysis was performed using the following models.

\section{PctChngAcres87-97=(ChangeRestrict87-97, Region, PctAcres87) PctChngFarms87-97=(ChangeRestrict87-97, Region, PctFarms87)}

where, PctChngAcres87-97 is the percentage change in acres under non-family corporate farms from 1987 to 1997; and, PctChngFarms87-97 is the percentage change in non-family corporate farms from 1987 to 1997 . ChangeRestrict87-97 is the restric-

\footnotetext{
${ }^{1}$ An analysis by Sommer and Hines (1991: 5) illustrates that this approach has validity since the major farming systems in the anti-corporate states are similar to the systems in the states bordering the anticorporate states and the Corn Belt states. We also analyzed data from the 1997 Census of Agriculture in which we compared percentages of farm types (beef, broiler poultry, dairy, hog, sheep, corn, sorghum, wheat, oat, soybean, nursery crops, and vegetable crops) identified by Sommer and Hines (1991) as components of the major commodity systems for the states within the two groups. The percentages of these farm types for the anti-corporate states and other central states tend to be similar. Mean percentages of the farms growing the above crops for the states in the two groups were not statistically different at the 0.05 level for all the commodities, except percentages of farms raising oats and nursery crops. Mean state percentages of oat farms and nursery farms were less than $10 \%$ and less than $1 \%$, respectively, for both groups of states.
} 


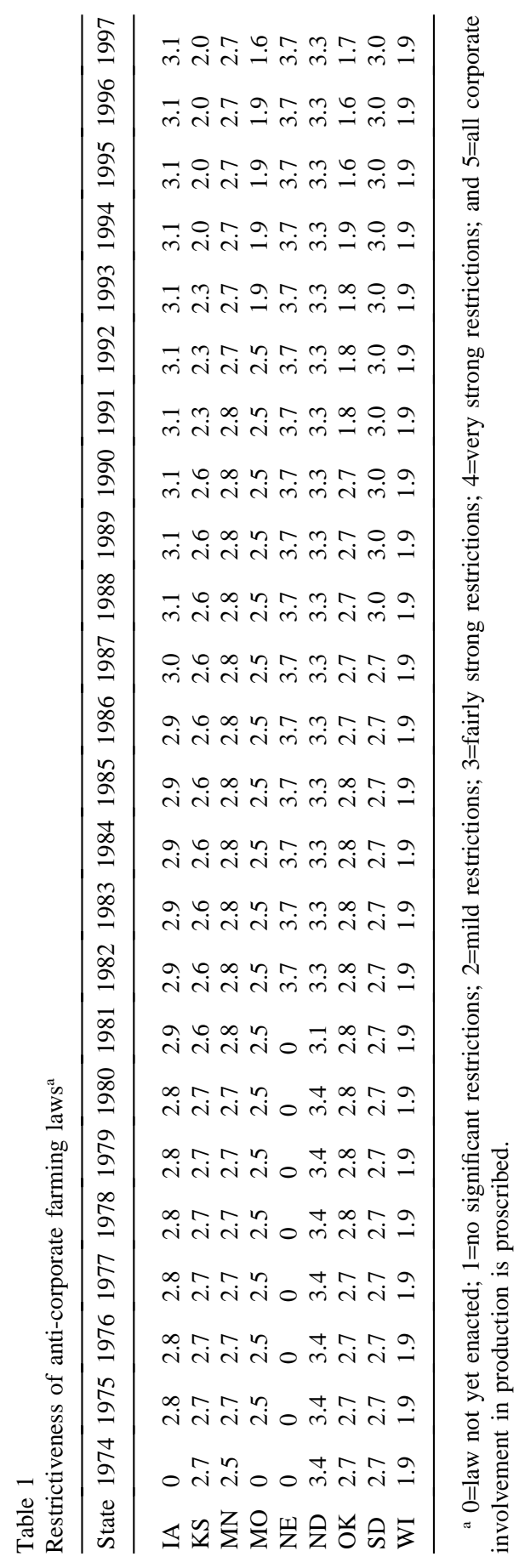


tiveness rating (from Table 1) in 1997 minus the rating in 1987. Since the significant changes in the laws were made between 1988 and 1995, and since the laws' ratings primarily moved either up or down, but not both, between 1987 and 1997, the end points are representative of the time period. For OC states this variable would have a zero value. Region is a binary $(0,1)$ variable where $\mathrm{AC}$ states are coded as 1 and OC states as 0 . PctAcres 87 is the percentage of acres under non-family corporate farms in 1987; and PctFarms87 is the percentage of non-family corporate farms in 1987. The latter two variables control for the differences between states regarding corporate acres and farms at the start of the period of interest. The restrictiveness rating for 1987 is not included as a control variable because it is highly correlated with Region.

The 1987-1997 time period was chosen to coincide with the availability of US Census data, because the last law was in place by 1982 and because after 1987, significant changes were made in the laws in several states. The dependent variables were selected because the laws were designed such that non-family corporations were more likely to have restrictions placed on them, and acreage limits have been one of the most common restrictions.

\section{Results and conclusions}

Turning first to the mail survey results in Table 1, most of the laws were rated as mildly to fairly restrictive by the agricultural lawyers. No laws were rated as very restrictive, and two of nine state laws were rated as at least fairly restrictive over the life of their laws - Nebraska and North Dakota. In addition, Table 1 indicates that from 1987 to 1997 the mean restrictiveness rating of all the laws dropped from 2.8 to 2.55 , and the difference between the highest rated law and the lowest also increased -1.8 to 2.1 . That is, the perceived restrictiveness of the laws in general has declined slightly and there has been increasing variation between state laws. For example, the restrictiveness ratings of Missouri, Oklahoma and Kansas declined to reflect changes made by the state legislatures. Specifically, Oklahoma's "clarification" of its law to attract corporate investment resulted in its rating dropping from 2.7 to 1.8 from 1990 to 1991 . Contrariwise, South Dakota strengthened its law in 1988, which was also reflected by an increase in the average rating from 1987 to $1988-2.7$ to 3.0 .

Turning to Table 2, the OLS results indicate that changes in the restrictiveness ratings significantly influence changes in acres under non-family corporate farms. Higher values of the index measuring changes in the laws' restrictiveness (i.e., strengthening the laws) were negatively related to changes in acres under non-family corporate ownership arrangements. That is, strengthening anti-corporate farming laws made it more likely a state would witness reductions, or smaller increases, in land under non-family corporate farms. Contrariwise, weakening laws had a positive impact on acres under non-family corporate ownership arrangements. Region had no impact.

Interestingly, the results regarding percent changes in non-family corporate farms indicate that strengthening a law has a positive effect on the percentage change in 
Table 2

OLS Regression Results: Percentage change in non-family corporate farms and acres from 1987 to $1997^{\mathrm{a}}$

\begin{tabular}{lcc}
\hline Explanatory Variable & Acres & Farms \\
\hline Change in laws' restrictiveness & $-6.957^{* * *}$ & $0.303^{\mathrm{a}}$ \\
& $(2.404)$ & $(0.160)$ \\
Anti-corporate farming state & 0.703 & -0.019 \\
& $(1.723)$ & $(0.106)$ \\
Percentage of non-family & 1.514 & - \\
farm acres in 1987 & $(88.376)$ & $-135.227^{* *}$ \\
Percentage of non-family & - & $(38.901)$ \\
farms in 1987 & 0.004 & $0.886^{* *}$ \\
Intercept & $(1.346)$ & $(0.127)$ \\
& 3.92 & 4.84 \\
Adj $R^{2}$ & 0.32 & 0.37 \\
\hline
\end{tabular}

${ }^{\mathrm{a}} p \leq 0.10 ; *=p \leq 0.05 ; * *=p \leq 0.01$

non-family corporate farms, though the relationship is not strong $(p \leq 0.10)$. This seems counter intuitive. However, an earlier legal analysis by Dahl (1991) indicates that some parties might try to circumvent the acreage limitations in the laws by establishing more than one corporation. Stronger laws, which limit corporate farm size, may provide an incentive to establish more corporate farms.

In conclusion, anti-corporate farming laws have been effective, if effectiveness is defined as limiting the acreage under non-family corporate ownership arrangements. These results help explain the continuing debates and efforts to establish, strengthen and weaken this type of law. Since changes in the laws have real effects, there is a basis for people who disagree on the appropriate role of corporations in agriculture to conflict over the need for the laws. Based on the results from this analysis, state governments and citizens have clear policy options. If the citizenry wishes to limit the expansion of farm land under non-family corporate ownership arrangements, then using the laws of states such as Nebraska or perhaps South Dakota, as models is advised. On the other hand, if corporate expansion is a goal, then states with anticorporate laws should follow the lead of other states such as Oklahoma or Missouri and weaken the laws.

\section{References}

Dahl, D., 1991. The Minnesota Corporate Farm Law. Minnesota Agricultural Economist 667, 1-5.

Hamilton, N., 1995. State Regulation of Production Contracts. University of Memphis Law Review 25, 1053-1106.

Patton, M.Q., 1990. Qualitative Evaluation and Research Methods. Sage Publications,

Pedersen, D.B., Meyer, K.G., 1995. Agricultural Law in a Nut Shell. West Publishing Company, St. Paul, MN.

Welsh, R., 1998. The Importance of Ownership Arrangements in U.S. Agriculture. Rural Sociology 63, 199-213. 